\title{
Diagnosis and Treatment of Hypertensive Pregnancy Disorders. Guideline of DGGG (S1-Level, AWMF Registry No. 015/018, December 2013)
}

\author{
Diagnostik und Therapie hypertensiver Schwangerschaftserkrankungen. \\ Leitlinie der DGGG (S1-Level, AWMF-Registernummer 015/018, Dezember 2013)
}

Authors

Affiliations
H. Stepan ${ }^{1}$, S. Kuse-Föhl ${ }^{2}$, W. Klockenbusch ${ }^{3}$, W. Rath ${ }^{4}$, B. Schauf ${ }^{5}$, T. Walther ${ }^{6}$, D. Schlembach ${ }^{7}$

The affiliations are listed at the end of the article.

\section{Key words \\ - preeclampsia \\ - hypertension \\ - HELLP syndrome \\ Schlüsselwörter \\ - Präeklampsie \\ - Hypertonie \\ - HELLP-Syndrom}

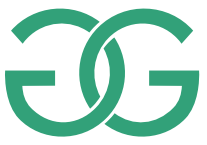

\section{OEGGG}

\section{gynécologie suisse}

Deutsche Version unter: www.thieme-connect.de/ ejournals/gebfra

\section{Bibliography}

Dol http://dx.doi.org/

10.1055/s-0035-1557924

Geburtsh Frauenheilk 2015; 75 : 900-914 @ Georg Thieme Verlag KG Stuttgart · New York . ISSN 0016-5751

\section{Correspondence}

PD Dr. med.

Dietmar Schlembach

Klinik für Geburtsmedizin

Vivantes Klinikum Neukölln

Rudower Straße 48

12351 Berlin

dietmar.schlembach@

vivantes.de

\section{Abstract \\ $\nabla$}

Purpose: Official guideline published and coordinated by the German Society of Gynecology and Obstetrics (DGGG). Hypertensive pregnancy disorders contribute significantly to perinatal as well as maternal morbidity and mortality worldwide. Also in Germany these diseases are a major course for hospitalization during pregnancy, iatrogenic preterm birth and long-term cardiovascular morbidity.

Methods: This S1-guideline is the work of an interdisciplinary group of experts from a range of different professions who were commissioned by DGGG to carry out a systematic literature search of positioning injuries. Members of the participating scientific societies develop a consensus in an informal procedure. Afterwards the directorate of the scientific society approves the consensus. Recommendations: This guideline summarizes the state-of-art for classification, risk stratification, diagnostic, treatment of hypertensive pregnancy disorders.

\section{Guideline Information}

\section{Guidelines Program of DGGG, OEGGG} and SGGG

Information on this topic is provided at the end of the guideline.

\section{Citiation format}

Diagnosis and treatment of hypertensive pregnancy disorders. Guideline of DGGG (S1-Level, AWMF Registry No.015/018, December 2013). Geburtsh Frauenheilk 2015; 75: 900-914

\section{Zusammenfassung \\ $\nabla$}

Ziel: Offizielle Leitlinie, publiziert und koordiniert von der Deutschen Gesellschaft für Gynäkologie und Geburtshilfe (DGGG). Hypertensive Schwangerschaftserkrankungen verursachen weltweit einen hohen Anteil an der neonatalen und mütterlichen Morbidität und Mortalität. Auch in Deutschland tragen sie wesentlich zu Krankenhauseinweisungen während der Schwangerschaft, iatrogener Frühgeburtlichkeit und kardiovaskulärer Langzeitmorbidität bei.

Methoden: Mitglieder der beteiligten Fachgesellschaften entwickeln in einem informellen Prozess einen Konsensus. Anschließend bestätigen die Direktorien der Fachgesellschaften diesen Konsensus.

Empfehlungen: In der Leitlinie wird der aktuelle Standard für die Benennung, Früherkennung, Diagnostik, Behandlung und Nachsorge hypertensiver Schwangerschaftserkrankungen gegeben. 
Table 1 Authors.

\begin{tabular}{ll}
$\begin{array}{l}\text { Author } \\
\text { Mandate holder } \\
\text { Coordinating lead author: }\end{array}$ & DGGG working group/professional association/organization/society \\
\hline $\begin{array}{l}\text { Prof. Dr. Holger Stepan } \\
\text { Other lead guideline authors: }\end{array}$ & German Society of Gynecology and Obstetrics (Deutsche Gesellschaft für Gynäkologie und Geburtshilfe [DGGG]) \\
\hline $\begin{array}{l}\text { PD Dr. Dietmar Schlembach } \\
\text { Other members of the task force: }\end{array}$ & Pregnancy Hypertension/Gestosis Working Group of DGGG \\
\hline $\begin{array}{l}\text { Sabine Kuse-Föhl } \\
\text { Prof. Dr. med. Walter Klockenbusch }\end{array}$ & Arbeitsgemeinschaft Gestose-Frauen e. V. \\
\hline $\begin{array}{l}\text { Prof. Dr. med. Werner Rath } \\
\text { Prof. Dr. med. Burkhard Schauf }\end{array}$ & International Society for the Study of Hypertension in Pregnancy (ISSHP) \\
\hline Prof. Dr. med. Thomas Walther & International Society for the Study of Hypertension in Pregnancy (ISSHP) \\
\hline
\end{tabular}

\section{Abbreviations}

$\begin{array}{ll}\text { ACE } & \text { Angiotensin Converting Enzyme } \\ \text { ASS } & \text { acetylsalicyl acid } \\ \text { BMI } & \text { Body-Mass-Index } \\ \text { CTG } & \text { Cardiotocography } \\ \text { DIG } & \text { disseminated intravascular coagulation } \\ \text { E } & \text { eclampsia } \\ \text { EFCNI } & \text { European Foundation for the Care of Newborn Infants } \\ \text { FPR } & \text { false positive rate } \\ \text { HELLP } & \text { Haemolysis Elevated Liver enzymes } \\ & \text { Low Platelet count } \\ \text { K } & \text { Korotkoff } \\ \text { LR } & \text { Likelihood ratio } \\ \text { MoM } & \text { multiple of the median } \\ \text { PAPP-A } & \text { pregnancy- associated plasma protein A } \\ \text { PE } & \text { preeclampsia } \\ \text { PIGF } & \text { placental growth factor } \\ \text { PI } & \text { pulsatility index } \\ \text { RI } & \text { Resistance-Index } \\ \text { RR } & \text { relative risk } \\ \text { SSW } & \text { week of gestation } \\ \text { SFlt-1 } & \text { soluble fms-like tyrosine kinase-1 }\end{array}$

\section{Using this Guideline}

\section{Purpose and objectives}

Hypertensive pregnancy disorders contribute significantly to perinatal as well as maternal morbidity and mortality worldwide. Also in Germany these diseases are a major course for hospitalization during pregnancy, iatrogenic preterm birth and longterm cardiovascular morbidity. The guideline summarizes the state-of-art for classification, risk stratification, diagnostic, treatment of hypertensive pregnancy disorders with the aim to reduce perinatal as well as maternal morbidity and mortality.

\section{Patient care}

Outpatient and inpatient care.

\section{Target audience}

This guideline is addressed to the following groups of people:

- Obstetricians

Audience of patients:

- pregnant women

\section{Period of validity}

The validity of this guideline was confirmed by the boards/responsible persons of the participating professional associations/ working groups/organizations/societies as well as by the board of the DGGG and the DGGG Guideline Commission in November 2013 and thereby approved in its entirety. This guideline is valid from December 01, 2013 to November 30, 2016. The period of validity has been estimated based on the guideline's contents. The guideline can be updated earlier if necessary; likewise, the guideline's period of validity can be extended if it continues to mirror the current state of knowledge.

\section{Guideline}

\section{$1 \quad$ Methodology}

The methodology for the compilation of this guideline is prescribed by the classification assigned to the guideline. The AWMF Guidance Manual and Rules for Guideline Development (Version 1.0) sets out the rules for classifying guidelines. Guidelines are differentiated into lowest (S1), moderate (S2) and highest (S3) class. The lowest class of guideline is defined as consisting of a set of recommendations for action compiled by a representative group of experts from medical societies. In 2004 the S2 class is divided into two subclasses: S2e (evidence-based) and S2k (consensus-based). The highest class (S3) combines both approaches. This guideline is classified as: $\mathrm{S} 1$

The guideline, which was created in November 1999 and was already present in a previous version from 2008, was adapted according to the current literature and existing international guidelines. The contents of the guideline have been edited by the entire group of experts in three meetings in debated discussions. After editorial and content revision of the guidelines by the management of the expert group, agreement between the authors took place using written correspondence. A version was adopted which was accepted by all authors. The Guidelines Commission and Board of DGGG accepted the guideline in November 2013.

\section{Introduction}

Hypertensive disorders occur in $6-8 \%$ of all pregnancies, contribute to $20-25 \%$ of perinatal mortality and are the first and second most common causes of maternal death in Europe. Preeclampsia is of particular importance (10-15\% of all maternal deaths are associated with preeclampsia/eclampsia) and is responsible for at least 70000 maternal deaths per year worldwide (for review: Lo et al. [1]). Even today, $>90 \%$ of maternal deaths from PE/E in Eu- 
rope are potentially avoidable [2,3]. In Europe, the incidence of preeclampsia is approximately $2 \%[1,4,5]$.

\section{Classification of hypertensive disorders in pregnancy and postpartum}

The following classification, as well as the definitions, takes into account the recommendations of the American and Australian Societies and the International Society for the Study of Hypertension in Pregnancy [6-11].

\subsection{Gestational hypertension \\ (Pregnancy-induced hypertension)}

Definition: Blood pressure values $\geq 140 / 90 \mathrm{mmHg}$ without proteinuria in a previously normotensive pregnant women occurring after the completed 20th week of pregnancy.

Cave: Mild preeclampsia develops from gestational hypertension in up to $46 \%$ of cases and severe preeclampsia develops in $9.6 \%$ [12].

\subsection{Preeclampsia (Synonym: Gestosis)}

Definition: Gestational hypertension and proteinuria $(\geq 300 \mathrm{mg} /$ $24 \mathrm{~h}$ detected in 24 -h urine or $>30 \mathrm{mg} / \mathrm{mmol}$ protein-creatinine ratio in a random urine sample occurring after the 20th completed week of pregnancy.

Cave: Clinical signs of renal impairment, hepatic involvement, pulmonary, haematological/neurological disorders or fetal growth restriction indicate the development of preeclampsia.

Based on the different pathophysiology and the different risk profile for mother and child, a distinction is made between early (early-onset manifestation < 34 weeks) and later (late-onset) preeclampsia $[13,14]$.

Preeclampsia is referred to as severe preeclampsia if at least one of the following criteria is also satisfied $[8,11,15]$ :

- Blood pressure $\geq 160 / 110 \mathrm{mmHg}$

- Renal impairment (creatinine $\geq 79.6 \mu \mathrm{mol} / \mathrm{l}$ [equates to $0.9 \mathrm{mg}$ / dl] or oliguria $<500 \mathrm{ml} / 24 \mathrm{~h}$ )

- Liver involvement (transaminase increase, persistent upper abdominal pain)

- Lung oedema

- Haematological disorders (thrombocytopenia < $100 \mathrm{Gpt} / \mathrm{l}$, haemolysis)

- Neurological symptoms (severe headache, impaired vision)

- Fetal growth retardation (estimated fetal weight $<5$. percentile and/or pathological umbilical artery Doppler)

The degree of proteinuria is no longer a criterion for the definition of serious preeclampsia $[11,15]$.

\subsection{Eclampsia}

Definition: Tonic-clonic seizures occurring during preeclampsia which cannot be attributed to any other cause.

Cave: Only associated with severe hypertension in about $50 \%$ and possible even in the absence of hypertension or proteinuria (14$34 \%$ of cases) [16,17]. $21 \%$ of women have no clinical symptoms in the week before the onset of preeclampsia [18].

\subsection{HELLP syndrome}

Definition: Triad of:

(H): haemolysis

(EL): elevated liver enzymes

(LP): low platelets (<100 Gpt/l)
Cave: There is no significant proteinuria in 5-15\%, no hypertension in up to $20 \%$ of cases and hypertension and proteinuria can both be absent at the same time [19].

\subsection{Chronic hypertension}

Definition: Hypertension $\geq 140 / 90 \mathrm{mmHg}$ diagnosed preconceptually or in the first half of pregnancy (before the 20th week of pregnancy) [20].

\subsection{Superimposed preeclampsia}

Definition: Chronic hypertension and newly emerged/worsening proteinuria after 20 weeks of pregnancy or appearance of clinical or laboratory features of severe preeclampsia (see above).

Cave: Superimposed preeclampsia develops from chronic hypertension in $17-25 \%$ ( $50 \%$ of these before the 34 th week of pregnancy) [20].

\section{$4 \quad$ Screening, prediction and prevention}

A significant, single test for reliable early recognition of preeclampsia is not yet available [4,21-26]. Anamnestic details (pregnancy record), mean arterial blood pressure, biochemical markers and Doppler sonography can be used in the first or second trimester for risk assessment [27].

\subsection{Screening in the first trimester}

A risk assessment of maternal characteristics (age, medical history, body mass index, ethnicity), in conjunction with biophysical factors (after MoM adjusted pulsatility of the uterine artery, mean arterial blood pressure) and biochemical risk markers (e.g. pregnancy-associated plasma protein A [PAPP-A], placental growth factor [PIGF]) allows an individual risk calculation, in particular for early-onset preeclampsia.

With this combination of different methods, detection rates for early preeclampsia of 93.4 and $95.2 \%$ can be achieved with a false positive rate (FPR) of 5 or $10 \%$.

However, this algorithm has significantly poorer detection rates of 37.8 and $71.1 \%$ for late preeclampsia $[5,28]$.

The predictive value of the different biophysical and biochemical methods as the sole screening test is low and their use for the prediction of preeclampsia is not recommended because of the high FPR [4, 5,24,28-32]. However, the high negative predictive value $(>97 \%$ ) of the test method for early-onset preeclampsia or the development of intrauterine growth retardation should be emphasised [30,33,34]. Regional differences as well as socio-economic and ethnic factors can influence the results and their significance $[35,36]$ therefore their uncritical acceptance in routine clinical practice is not recommended (especially without appropriate organizational structures and adequate counselling) [37].

\subsection{Screening and prediction in the second trimester}

The measurement of the mean pulsatility index (PI) - alone or in combination with postsystolic notching - is considered the best marker for the prediction of preeclampsia with a sensitivity of up to $93 \%[22,23,38-40]$, in a low-risk group the recognition rate of the mean pulsatility index $>1.6$ (95th percentile) for early-onset preeclampsia at $5 \%$ FPR was $78 \%$ and $42.8 \%$ for preeclampsia overall [22]. The detection rates for late preeclampsia are significantly lower, depending on gestational age [22]. Of clinical relevance here is also the high specificity and negative predictive value of Doppler ultrasound parameters of up to $99 \%[38,39,41,42]$. The presentation of postsystolic notching in the uterine artery is 
a reliable sign when screening for preeclampsia; however the error rate is unfortunately high because of a certain subjectivity. A further risk estimation for the development of preeclampsia and prognostic assessment of the clinical course of the disease with a pathological uterine artery Doppler in the 2nd trimester can be achieved by determining angiogenesis/antiangiogenesis factors $[22,23,25,42-45]$. It has been shown that the serum levels of sFlt-1 (soluble fragment of the VEGF receptor 1) and PlGF already alter weeks before manifestation of the disease and that the sFlt-1/PIGF ratio has a prognostic value $[43,46-50]$.

\subsection{Prevention}

Currently the only effective way of preventing preeclampsia in women with risk factors (e.g. a history of severe preeclampsia) is to begin oral administration of low-dose acetylsalicylic acid (ASA: $75-150 \mathrm{mg} /$ day) during early pregnancy (before 16 weeks) [51]. This approach significantly reduces the risk of preeclampsia before the 37th week of pregnancy, but not near term [52], as well as the risk of (severe) preeclampsia, pregnancy-induced hypertension and IUGR with pathological uterine artery Doppler results [53].

In Germany, an aspirin dosage of $100 \mathrm{mg}$ /day up to $34+0$ weeks has been established. General aspirin prophylaxis is not indicated.

\section{$5 \quad$ Antenatal screening}

5.1 Risk factors for the development of preeclampsia

\subsubsection{Clinical history risk factors (OTable 2) [39, 54-62]}

\section{Table 2 Clinical history risk factors}

\begin{tabular}{|l|l|}
\hline & Relative risk (RR) \\
\hline Antiphospholipid syndrome & $\sim 9$ \\
\hline History of preeclampsia & $\sim 7$ \\
\hline Body Mass Index $>30$ & $\sim 3-5$ \\
\hline Pre-existing diabetes mellitus & $\sim 3.5$ \\
\hline Family history & $\sim 3$ \\
\hline Pre-existing kidney disease & $\sim 3$ \\
\hline First pregnancy & $\sim 2.5-3$ \\
\hline Age $>40$ & $\sim 2$ \\
\hline Chronic hypertension & $\uparrow$ \\
\hline - with 1 additional risk factor & 1.55 \\
\hline - with 2 additional risk factors & 3 \\
\hline BP diastolic $>110$ mmHg (<20 weeks) & 3.2 \\
\hline Autoimmune diseases & $7-9.7$ \\
\hline Ethnicity (African-American) & 2 \\
\hline
\end{tabular}

\subsubsection{Pregnancy-associated risk factors (॰ Table 3) [39, 56, 59, 62]}

Table 3 Pregnancy-associated risk factors.

\begin{tabular}{|l|l|} 
& $\begin{array}{l}\text { Relative risk (RR)/ } \\
\text { Likelihood ratio (LR) }\end{array}$ \\
\hline $\begin{array}{l}\text { Bilateral notching/ } \\
\text { increased PI/RI in the uterine artery } \\
\text { persisting > 24. SSW }\end{array}$ & $3.4-6.5$ \\
\hline Multiple pregnancy & \\
\hline IVF/egg cell donation & 3 \\
\hline Gestational diabetes & $\uparrow$ \\
\hline Hydrops fetalis, trisomies, molar pregnancy & \\
\hline
\end{tabular}

\subsubsection{Recurrence risk}

The recurrence risk for preeclampsia after previous preeclampsia is 11.5 to $27 \%$ [63], on average 14 to $16 \%$ [64-66], and $32 \%$ after two previous episodes of preeclampsia [66]. After previous pregnancy-induced hypertension, the risk of recurrence of the same disease in the following pregnancy is specified as $16-47 \%$ and $2-7 \%$ for preeclampsia $[11,64]$.

The recurrence risk for the occurrence of HELLP syndrome after a previous HELLP syndrome is $12.8 \%$ in Germany [67].

After eclampsia, there is a risk of recurrence of eclampsia of 2$16 \%$ in a subsequent pregnancy and of $22-35 \%$ for preeclampsia [68]. The risk of recurrence and the prognosis depends mainly on the gestational age of the baby ( $\leq 28$ week of pregnancy: $38.6 \%$; 29-32 weeks: $29.1 \%$; 33-36 weeks: $21.9 \%$; $\geq 37$. weeks: $12.9 \%)$ and the severity of preeclampsia in the previous pregnancy (recurrence risk of $25 \%$ after severe preeclampsia, HELLP syndrome or eclampsia before 34 weeks' gestation and $55 \%$ in severe preeclampsia before the 28th week of pregnancy) as well as other accompanying factors (e.g., elevated BMI) or disorders [65].

Cave: After preeclampsia/HELLP syndrome, the risk of other hypertensive disorders occurring during pregnancy is increased.

\subsection{Blood pressure measurement}

Diastolic blood pressure should be recorded as Korotkoff 5 (K5 = disappearance of sound) or Korotkoff 4 (muting) if K5 is not measurable [69-71]. The measurement should be carried out manually using a cuff which is adapted to the upper arm circumference $[7,72]$. The first measurement should be taken after a 2 to 3 minute rest period with the patient seated.7 The measurement should primarily be taken on both arms and later on the right arm if there are small differences.

24-hour blood pressure measurement is a suitable method to clarify a differential diagnosis of hypertension in pregnancy (to exclude "white coat hypertension", loss of circadian rhythm as a prognostically unfavourable sign) and to check the success of anti-hypertensive treatments [69,70].

Cave: Women with "white coat hypertension" in early pregnancy may develop pregnancy-induced hypertension in up to $40 \%$ of cases and preeclampsia in $8 \%$ later in pregnancy [73].

For the outpatient care of pregnant women, self-measurement of blood pressure is recommended (at least in the morning and evening) using an upper arm monitor and a blood pressure profile should be recorded.

Cave: Automatic blood pressure monitors are suitable for this purpose, however a wrist device can measure the blood pressure systematically lower [74,75].

\subsection{Protein excretion in the urine (proteinuria)}

Evidence of $\geq 1+$ protein in the urine screening test requires clarification.

A quantitative measurement of protein in urine should be performed in all patients with de novo hypertension in pregnancy $[11,76-78]$. Proteinuria before 20 weeks of pregnancy is an indicator of pre-existing kidney disease [79].

The following diagnostic criteria are available:

- Protein-creatinine ratio (from random urine sample) [11,8083]: Values $\geq 30 \mathrm{mg} / \mathrm{mmol}$ indicate significant proteinuria (corresponding to $\geq 300 \mathrm{mg} /$ day) and correlate with a proteinuria of $\geq 300 \mathrm{mg} /$ day. The use of catheter urine is not necessary [84].

- Protein excretion in 24-hour urine collection ( $\geq 300 \mathrm{mg} /$ day) $[11,72,78,85]$. 
Cave: In cases of confirmed proteinuria, repeated measurements to estimate the prognosis and monitoring of preeclampsia are not useful $[11,78]$.

\subsection{Oedema}

Oedema alone is an uncharacteristic symptom that is only relevant if it increases rapidly, i.e. if significant weight gain is detected within a short period of time $(\geq 1 \mathrm{~kg} /$ week in the III trimester) [86] or if there is pronounced facial oedema. If oedema/ weight gain develops rapidly in conjunction with proteinuria, it can lead to eclampsia even without hypertension (cf. definition of preeclampsia).

\section{$6 \quad$ Out-patient and clinical monitoring}

\subsection{Clinical chemistry and haematology}

The following clinical chemistry/haematological parameters can be altered, depending on the disorder ( Table 4) [6-11,49,8791]:

Table 4 Clinical chemistry laboratory parameters.

\begin{tabular}{|c|c|}
\hline \multicolumn{2}{|l|}{ Parameter } \\
\hline Haemoglobin & $>13 \mathrm{~g} / \mathrm{dl}=>8.0 \mathrm{mmol} / \mathrm{l}$ \\
\hline Haematocrit & $>38 \%$ \\
\hline Thrombocytes & $<100 \mathrm{Gpt} / \mathrm{I}$ \\
\hline \multicolumn{2}{|c|}{$\begin{array}{l}\text { A progressive decrease in platelet counts, even within the normal range, } \\
\text { should be monitored within a few hours (Cave: HELLP syndrome, DIC). }\end{array}$} \\
\hline GPT (ALT) & Rise above the normal range \\
\hline GOT (AST) & Rise above the normal range \\
\hline $\mathrm{LDH}$ & Rise above the normal range \\
\hline Bilirubin (indirect) & $>1.2 \mathrm{mg} / \mathrm{dl}=>20.5 \mu \mathrm{mol} / \mathrm{I}$ \\
\hline Uric acid & $>5.9 \mathrm{mg} / \mathrm{dl}=350 \mu \mathrm{mol} / \mathrm{l}$ \\
\hline Creatinine & $\geq 0.9 \mathrm{mg} / \mathrm{dl}=79.6 \mu \mathrm{mol} / \mathrm{l}$ \\
\hline Protein in urine & $\geq 300 \mathrm{mg} / 24 \mathrm{~h}$ \\
\hline Haptoglobin & Drop below the normal range \\
\hline $\begin{array}{l}\text { Other clotting tests (e.g. rapid } \\
\text { D-dimer increase (indicator of }\end{array}$ & Monitor \\
\hline PIGF & $\begin{array}{l}\text { Gestational age-specific } \\
\text { standard value }\end{array}$ \\
\hline sFlt-1/PIGF ratio & $>85$ \\
\hline
\end{tabular}

\subsection{Outpatient care}

With adequate cooperation between the pregnant women and excluded apparent risks for mother and child as well as guaranteed weekly medical checks, mild pregnancy-induced hypertension be treated in the outpatient clinic (including a home blood pressure protocol) $[11,92]$. In addition to physical rest and the elimination of additional stress factors (possible unfitness for work or individual work prohibition), regular measurements of blood pressure, body weight and monitoring of proteinuria are priority. In addition, the well-being of the fetus (growth, Doppler, CTG) and the estimation of amniotic fluid volume should be monitored.

The pregnant mother should be referred to the hospital if a hypertensive value of $150 / 100 \mathrm{mmHg}$ or above is measured.

The initiation of drug treatment is reserved for severe forms and should only be performed in hospital. To confirm the diagnosis of or to exclude preeclampsia, the angiogenic factors can be determined additively (PlGF, sFlt-1/PIGF ratio) [49,87-91].

\subsection{Indications for hospital referral [11,49, 93, 94]}

- Hypertension $\geq 150 \mathrm{mmHg}$ systolic or $\geq 100 \mathrm{mmHg}$ diastolic

- Apparent preeclampsia

- Proteinuria and severe weight gain in the III trimester $(\geq 1 \mathrm{~kg} /$ week)

- Impending eclampsia (Prodromal symptoms: upper abdominal pain, nausea, vomiting; CNS symptoms: visual snow, persistent headache, hyperreflexia)

- Clinical suspicion of HELLP syndrome, especially persistent upper abdominal pain

- Indicators of a threat to the fetus

- Suspicious/pathological CTG or suspicious/pathological Doppler scan

$>$ IUGR

- Mild hypertension or proteinuria and further risk factors such as

- Pre-existing maternal disorders (e.g. diabetes mellitus)

- Multiple pregnancy

- Early gestational age $(<34$ weeks)

- An-/Oligohydramnios

- Pathological sFlt-1/PlGF ratio

\subsection{Measures to be taken in hospital}

6.4.1 On admission

- Diagnosis of maternal and fetal condition (hypertensive or fetal emergency?):

- Fastest possible measurement of blood pressure on admission (repeat after adaptation phase if necessary) followed by close blood pressure measurement until stabilisation of blood pressure

- Exclusion of prodromal symptoms (central symptoms, upper abdominal pain)

- CTG recording (from fetal viability)

- Proteinuria diagnosis using test strips on admission and as part of quantitative protein measurement

- Laboratory according to hospital standard (see $\bullet$ Table 4)

- Ultrasound (biometry/Doppler scan)

6.4.2 After stabilisation

- Blood pressure monitoring depending on clinical symptoms

- CTG $(1-3 \times /$ day $)$

- Laboratory monitoring daily up to $2 \times$ per week (determination of angiogenic factors (sFlt-1/PlGF ratio) for differential diagnosis/short-term prognosis if necessary)

- Monitoring of clinical symptoms, especially upper abdominal pain, headache, blurred vision, hyperreflexia, (check reflex status), impairment of consciousness, dyspnoea, increased risk of bleeding

- Hourly monitoring of urine output in pregnant women with severe clinical symptoms of preeclampsia, pulse oximetry for respiratory symptoms (for example, dyspnoea)

- Fetometry every 10-14 days and measurement of amniotic fluid volume

- Doppler scan daily/weekly

- RDS prophylaxis (24 to 34 weeks) - individualised decision

- Daily weight monitoring

\section{Treatment}

\subsection{Basic aspects of drug treatment}

Initiation of drug treatment should be the sole responsibility of the hospital, since inpatient observation under controlled conditions may result in the need for a blood pressure lowering drug. This continues to be problematic in terms of fetal development 
Table 5 Long-term treatment with oral antihypertensives [95,101-103] as at 12/2013.

\begin{tabular}{|c|c|c|c|}
\hline & Drug & Dose & Notes \\
\hline Suitable & Alpha-Methyldopa & $\begin{array}{l}250-500 \mathrm{mg} \text { oral (bd - qds) } \\
\text { max. } 2 \mathrm{~g} / \text { day }\end{array}$ & First choice \\
\hline \multirow[t]{2}{*}{$\begin{array}{l}\text { Partially } \\
\text { suitable }\end{array}$} & Nifedipine retard & $\begin{array}{l}20-60 \mathrm{mg} \text { ret. oral } \\
\text { max. } 120 \mathrm{mg} / \text { day }\end{array}$ & No proven teratogenic effects \\
\hline & $\begin{array}{l}\text { Selective } \beta-1 \text { receptor } \\
\text { blocker (Metoprolol } \\
\text { agent of choice) }\end{array}$ & Dose $25-100 \mathrm{mg}(\mathrm{bd})$ & Increased risk of fetal growth restriction generally with $\beta$-blocker therapy \\
\hline \multirow[t]{4}{*}{$\begin{array}{l}\text { Not } \\
\text { suitable }\end{array}$} & Diuretics & & $\begin{array}{l}\text { Potential impairment of uteroplacental perfusion } \\
\text { from additional plasma volume reduction }\end{array}$ \\
\hline & ACE inhibitor & & $\begin{array}{l}\text { No proven teratogenic effects. Contraindicated in II/III trimester: } \\
\text { Acute renal failure in neonates, oligohydramnios }\end{array}$ \\
\hline & $\begin{array}{l}\text { Angiotensin } \\
\text { AT1 antagonists }\end{array}$ & & $\begin{array}{l}\text { Oligohydramnios, skull hypoplasia, potentially teratogenic } \\
\text { in analogy to ACE inhibitors and nephrotoxic for the newborn }\end{array}$ \\
\hline & $\begin{array}{l}\text { All other } \\
\text { antihypertensives }\end{array}$ & & Insufficient information on use in pregnancy \\
\hline
\end{tabular}

and should therefore not be initiated below a persistent blood pressure of $\geq 150 \mathrm{mmHg}$ systolic and/or $\geq 100 \mathrm{mmHg}$ diastolic and at the latest at a value of $\geq 160 / 110 \mathrm{mmHg}[6,11,95]$. The target blood pressure levels should be $<150 \mathrm{mmHg}$ systolic and 80 $100 \mathrm{mmHg}$ diastolic [11].

According to current knowledge, antihypertensive treatment in severe hypertension is used to prevent maternal cerebrovascular/cardiovascular complications. The focus is on prevention of cerebral haemorrhage and supplementation with i.v. magnesium is required for effective eclampsia prophylaxis [96-100].

A benefit for fetal development and therefore improvement of the baby's prognosis by drug blood pressure reduction has not yet been proven.

Patients with infertility and chronic hypertension should be treated with drugs that are indicated in pregnancy $[11,20]$.

The physiological blood pressure in the first half of pregnancy has to be considered when drug treatment is used to control chronic blood pressure in pregnancy (dose reduction or discontinuation of medication if necessary).

\subsection{Long-term treatment with oral antihypertensive agents}

If general measures do not succeed in keeping the blood pressure at $<150 / 100 \mathrm{mmHg}$, antihypertensive drug therapy must be initiated or intensified or pre-existing medication must be resumed. Potential effects on fetal development must be considered when considering the choice of antihypertensive agent (see $\square$ Table 5).

\subsection{Treatment of severe hypertensive pregnancy disorders \\ 7.3.1 Antihypertensive treatment}

Initial antihypertensive treatment of severe hypertension (blood pressure $\geq 160 / 110 \mathrm{mmHg}$ ) should be carried out under CTG monitoring, as a pronounced drop in blood pressure may be associated with an acute threat to the fetus. Patients should be closely monitored and regular blood pressure checks (at least once every $10-15 \mathrm{~min}$ ) are necessary $[15,104]$. The diastolic target blood pressure should not fall below $80-100 \mathrm{mmHg}[11,97,104]$.

A severe hypertensive pregnancy disorder is present if hypertension cannot be successfully treated with oral hypertensives (s. 6.2 ) or a hypertensive emergency exists. A hypertensive emergency (prolonged acute severe hypertension for over 15 min with vital hazards caused by organ damage, e.g. hypertensive encephalopathy with blurred vision, dizziness, severe headache, decreased consciousness, neurological deficits or pulmonary oedema) requires immediate drug treatment to reduce blood pressure $[71,104,106,107]$.

The medication available in Germany, nifedipine and urapidil, can both be used without preference for the initial treatment of severe hypertension $[103,108]$. However, the off-label use of nifedipine and urapidil must be observed (see $\bullet$ Table 6 ).

Dihydralazine is approved for antihypertensive therapy during pregnancy; however it has significantly more maternal side-effects than urapidil (especially severe headaches, reflex tachycardia), which can complicate the differential diagnosis in relation to the progression of preeclampsia [108,109].

According to a meta-analysis, dihydralazine is associated with a higher rate of maternal side-effects (including severe hypotension) and perinatal complications (including placental abruption) compared to nifedipine, without a definitive assessment being possible according to the authors $[110,111]$.

To reduce the risk of sudden severe hypotension with subsequent risk to the fetus, up to $500 \mathrm{ml}$ of intravenous electrolyte solution should be infused prior to the administration of dihydralazine [11].

\subsubsection{Anticonvulsive treatment}

The treatment of choice for the prevention of eclampsia is the intravenous administration of magnesium sulphate which is indicated in severe preeclampsia, especially where there are central nervous system symptoms, as a significant reduction in the risk if eclampsia can be achieved with magnesium sulphate [112116]. The effectiveness of this seizure prophylaxis is less clear for mild preeclampsia, but is under discussion after a large-scale study with $>10000$ pregnancy women with mild and also with severe preeclampsia showed a halving of the eclampsia risk with magnesium sulphate $(1 \mathrm{~g} / \mathrm{h})$ compared to placebo $[99,117,118]$. Magnesium sulphate is also the drug of first choice in manifest eclampsia [112-116]. Superiority over phenytoin as well as diazepam in the prevention of re-convulsions and in terms of neonatal results has also been shown $[112,114,115,119]$. Intravenous therapy (see Table 6) is with a loading dose of 4-6 $g$ of diluted magnesium sulphate administered over 15-20 min via syringe driver or short infusion and continued with a maintenance dose of $1 \mathrm{~g} / \mathrm{h}[120]$. 
Table 6 Acute drug treatment: Substances and doses $[1,11,101,102,104,107]$.

\begin{tabular}{|c|c|c|c|}
\hline & Drug & & Dosage \\
\hline \multirow[t]{5}{*}{ Antihypertensive therapy } & Nifedipine & oral & initially $5 \mathrm{mg}$ oral, repeat after $20 \mathrm{~min}$ if necessary \\
\hline & Urapidil & i.v. & $\begin{array}{l}\text { initially } 6.25 \text { slow i.v. (over } 2 \mathrm{~min} \text { ) } \\
\text { followed by } 3-24 \mathrm{mg} / \mathrm{h} \text { (via syringe driver) }\end{array}$ \\
\hline & Dihydralazine & i.v. & $\begin{array}{l}\text { initially } 5 \mathrm{mg} \text { i.v. (over } 2 \mathrm{~min} \text { ) } \\
\text { followed by } 2-20 \mathrm{mg} / \mathrm{h} \text { (via syringe driver) } \\
\text { or } \\
5 \mathrm{mg} \text { every } 20 \mathrm{~min}\end{array}$ \\
\hline & With pulmona & leart $f$ & \\
\hline & Furosemide & i.v. & $\begin{array}{l}10-20 \mathrm{mg} \\
\text { Repeat with increased dose if necessary after } 500 \mathrm{ml} \text { volume support }\end{array}$ \\
\hline Anticonvulsive treatment & Magnesium & i.v. & $\begin{array}{l}\text { initially } 4-6 \mathrm{~g} \text { (in } 50 \mathrm{ml} \text { ) over } 15-20 \mathrm{~min} \text { (as short infusion or via syringe driver) } \\
\text { Maintenance dose: } 1 \mathrm{~g} / \mathrm{h}\end{array}$ \\
\hline
\end{tabular}

The patient should be closely monitored and the reflex state (patellar reflex), respiratory rate (should not fall below 12 breaths/ $\mathrm{min}$ ) and renal function (at least $100 \mathrm{ml}$ excretion within 4 hours) generally suffice here. Calcium should be readily available for immediate intravenous injection as an antidote $(1 \mathrm{vial}=10 \mathrm{ml}$ of $\mathrm{i} . \mathrm{v}$. calcium gluconate $10 \%$ slowly over $3 \mathrm{~min}$ ).

Alternatively, anticonvulsant therapy with diazepam or phenytoin can be given if transport is in the ambulance.

\subsubsection{Volume expansion}

Accompanying volume therapy has not shown any treatment advantages in previously conducted randomized trials [121,122]. Sufficient oral volume intake should be maintained.

\section{$8 \quad$ Indications for delivery}

Delivery is the only causal therapy for pregnant women with preeclampsia. Prolongation of the pregnancy is primarily to prevent preterm birth and assumes an expected benefit for the baby. The decision to deliver is thus highly dependent on the gestational age and is usually indicated after the 37th completed week of pregnancy $[11,12,72,123]$.

\subsection{Preeclampsia after the completed 34th to 37th week of pregnancy ( $34+0$ to $36+6$ weeks)}

After the completed 34th week, every patient with severe preeclampsia should be delivered as soon as possible $[8,11]$. This also applies in cases of severe fetal growth restriction $<5$ th percentile with concurrent pathological fetal or fetal-placental blood flow such as absent or reversed flow in the umbilical artery [124132].

However, of lesser importance is the amount of amniotic fluid which, compared to IUGR, appears to have no isolated effect on pregnancy outcome in preeclampsia $[133,134]$. Prolongation of pregnancy beyond the 37th week is not advisable in mild preeclampsia or pregnancy-induced hypertension [123].

In mild forms, the increased morbidity of a late preterm delivery should be considered beyond 34 weeks (34th to 37th week of pregnancy) $[135,136]$. The mortality of "later preterm infants" is increased compared to full-term babies ( 3.5 to 5.5-fold). Postnatal late mortality (28 days - 12 months) is twice as high [137]. In contrast is the risk of intrauterine fetal death, which is $3 / 1000$ pregnancies at the end of pregnancy ( $>36+0$ weeks).

The rate rises to $21 / 1000$ in severe preeclampsia [138]. The IUFD rate is much lower (9/1000) in women with mild preeclampsia. The neonatal complication rate increases with the degree of fetal growth restriction (especially < 10th percentile). Women with severe preeclampsia especially have growth retarded infants
( $>12 \%$ compared to healthy women). Significant fetal weight reduction is not observed in mild preeclampsia [139].

\subsection{Preeclampsia after the completed 24th to 34th week of pregnancy $(24+0$ to $33+6$ weeks)}

Patient care should take place in a perinatal centre. A primary conservative approach is recommended because there are hardly any serious effects on the mother, but clear benefits for the child can be expected under continuous monitoring [140-142]. A fundamentally similar approach appears justifiable for HELLP syndrome $[143,144]$. Severe fetal growth restriction $<5$ th percentile alone does not constitute a clear indication for delivery in cases of severe preeclampsia before the 34th week as long there are no highly pathological Doppler results [127,132,145].

The assessment of the risk and the potential benefit of watchful waiting approach must be continuously reassessed, taking into account all maternal and fetal changes. In addition to the considerable importance of gestational age, the question of completed RDS prophylaxis plays an important role in making an individual decision.

In addition to fetal indications are the following maternal indications for delivery. In each individual case, the value of completing RDS prophylaxis should be weighed against the urgency of ending the pregnancy for a maternal indication $[6,11,146]$.

- Refractory severe hypertension

- Refractory renal failure

- Cardiac decompensation

- Acute lung oedema

- Disseminated intravascular coagulation

- Persistent severe upper abdominal pain

- Newly developing serious central nervous system symptoms

- Eclampsia

\subsection{Preeclampsia $\leq 24$ th week}

Significant maternal and perinatal morbidity and mortality are to be expected [147-149]. The decision to continue the pregnancy should be made individually. The focus is on the avoidance of maternal complications.

\subsection{Method of delivery}

Vaginal delivery can be tried if the maternal and fetal conditions are stable as there is no increased risk to the baby with optimum monitoring. The severity and the dynamics of the disease and the chances of success of a vaginal birth (e.g. cervical ripening) should be considered when deciding on the method of delivery $[151,152]$. 
9

Postnatal care

Cave: Postpartum HELLP syndrome (7-30\%) and postpartum eclampsia (up to $28 \%$ ) $[68,153]$.

- Continuation of intensified monitoring up to 48 hours postpartum

- In severe preeclampsia: magnesium sulphate i.v. up to 48 hours postpartum

- Blood pressure monitoring postpartum until normalisation of blood pressure; guidance on self-monitoring of blood pressure [154]

- Target blood pressure on discharge $<150 / 100 \mathrm{mmHg}$

- Tapered dose reduction or alteration of antihypertensive treatment

\subsection{Drug treatment}

- In pregnancy-associated hypertension, tapered dose reduction of antihypertensive drug treatment is usually possible within 3 days to 6 weeks postpartum in most cases.

- If blood pressure has not normalized up to 6 weeks postpartum: diagnosis and treatment as recommended by the German Hypertension Society $[155,156]$.

Continuation of ongoing treatment or conversion to oral medication if necessary (metoprolol, nifedipine, alpha-methyldopa) $[103,156]$.

\subsection{Breast feeding}

Discontinuation of breast feeding because of an antihypertensive drug treatment is usually not necessary with the large selection of antihypertensives which are compatible with breast feeding [103].

\subsection{Counselling}

A final discussion with the patient about the disease, the individual course and other consequences is essential, in the presence of her partner if possible, with the offer of meeting again, e.g. before planning/occurrence of another pregnancy [157,158]. Referral should be made to self-help groups, e.g. Arbeitsgemeinschaft Gestose-Frauen e.V. (Women's Gestosis Working Group, www. gestose-frauen.de), Bundesverband der Frühgeborenen e.V. (Federation of Premature Babies e.V., http://www.fruehgeborene.de) and European Foundation for the Care of Newborn Infants (EFCNI: www.efcni.org; www.enemenemini.eu/de/Home). Use of oral contraception is possible after preeclampsia/HELLP syndrome [159].

\section{Care after preeclampsia}

10.1 Further diagnostics after the postpartum period

- Measurement of serum creatinine and proteinuria, including microalbuminuria, proteinuria ideally from a $24 \mathrm{~h}$ urine collection

- Evaluation of possible kidney damage 3 months postpartum [160-163]

- Referral to a nephrologist if there is persistent proteinuria and/ or increased serum creatinine

- In severe preeclampsia - clarification of antiphospholipid syndrome/systemic lupus erythematosus [164]

\subsection{Follow-up of infants}

Monitoring and follow-up is based on the general guidelines. This particularly applies to growth-retarded infants and premature births. An additional examination of sensory integration disorders should be planned the first year of life and also for full-term infants or for infants born after 34 weeks. Another additional examination is recommended in the third year of life, preferably in a socio-paediatric centre.

\subsection{Future life - planning further pregnancies}

- Point out to the patient the increased risk of cardiovascular disease for both mother and child [165-183]

- Inform the patient about the risk of recurrence after preeclampsia/HELLP syndrome (see above) [65, 67, 184-188]

- Diagnosis and treatment where appropriate of cardiovascular risk factors (nicotine, blood lipids, diabetes, metabolic syndrome, lifestyle changes) [167,170,174,176]

- Consultation (internist, gynaecologist) before planned pregnancy (including prevention) [162,189,190]

\section{Special features of HELLP syndrome \\ 11.1 Diagnosis}

The diagnosis is made by laboratory tests with evidence of the triad of haemolysis, elevated liver enzymes and thrombocytopenia [191]:

(H): haemolysis (Haptoglobin $\downarrow$ )

(EL): elevated liver enzymes (Transaminases $\uparrow$ [GOT, GPT])

(LP): low platelets (Thrombocyte count $\downarrow[<100 \mathrm{G} / 1]$ )

The following clinical symptoms can occur simultaneously [164, 192]:

- Right-sided upper abdominal pain/epigastric pain: > 90\%

- Hypertension: $80 \%$

- Proteinuria: up to $15 \%$

- Both proteinuria and hypertension may be missing in HELPP syndrome (HELLP syndrome without preeclampsia)

- Possible neurological symptoms

11.1.1 Laboratory parameters

Clinical chemistry tests should initially be repeated at $6-8$ hourly intervals, especially when they are only discrete at the start of the disorder or are not completely altered in terms of the classic triad $[164,193]$.

Evidence of haemolysis is best performed by determining haptoglobin (decreased in $95-97 \%$ of patients, the most sensitive parameters of haemolysis) [164,193-199].

Further haemolysis parameters [164]:

- Detection of fragmentocytes in a peripheral blood smear (54$86 \%)$

- Total bilirubin raised (47-62\%)

LDH is not a haemolysis-specific parameter in HELLP syndrome $[164,192,196,197]$; however it correlates with the severity of the disease [200].

An increase in C-reactive protein is detected in up to $62 \%$ of cases of HELLP syndrome and is not a result of infection [199,201205].

11.1.2 Pain symptoms

Right-sided upper abdominal pain/epigastric pain may occur with HELLP syndrome, even before laboratory evidence of HELLP syndrome. Pain may also be retrosternal. If right upper quadrant abdominal pain or retrosternal pain occurs after the 18th week, HELLP syndrome must be excluded in the differential diagnosis or confirmed.

11.1.3 Clinical course

Fluctuating in spurts, with possible remissions in up to $46 \%$ of cases or exacerbation within hours [143], in particular the development of coagulopathy (DIG) occurs more often than with preeclampsia (no heparin administration, haemostasis correction with fresh frozen plasma if necessary) $[153,164,193]$. 


\subsubsection{Indications for delivery}

Fetal indications for delivery The indications for delivery of a fetal perspective correspond with the general indications for delivery (see. Chap. 8) using the recognised diagnostic methods (Doppler sonography, biometrics, CTG, fetal heart rate variability) taking into account the gestational age.

Maternal indications for delivery The indications for delivery from a maternal perspective are based on the maternal condition. With the aim of reducing neonatal morbidity and mortality, a conservative approach - preferably in a perinatal centre [206] is recommended at a gestational age of below 34 weeks, at least until clinical stabilization $[19,141,143,164,206-210]$. The indications for immediate ending of a pregnancy are based on the maternal and fetal indications of severe preeclampsia. A pregnancy should be ended especially if there is associated, severe or treatment-refractory preeclampsia, disseminated intravascular coagulation (DIG), severe renal insufficiency, congestive heart failure or pulmonary oedema [19,143,164,206, 208].

Logistical requirements for prolongation of a pregnancy are the intensive monitoring of mother and child, the availability of frequent laboratory controls, the possibility of immediate ending of the pregnancy by Caesarean section and close interdisciplinary cooperation with neonatology and anaesthesiology. The therapeutic approach to stabilize the maternal situation is generally based on the criteria described for severe preeclampsia [193, 208,210].

If HELLP syndrome is confirmed, pregnancy should be ended after 34 weeks of pregnancy. A vaginal delivery can be tried if the maternal and fetal conditions are stable. There is currently insufficient clinical experience for induction of labour (e.g. with prostaglandins) in HELLP syndrome. It should be noted that when HELLP syndrome occurs, the cervix is often unripe and the duration and success of labour induction are therefore unforeseeable $[193,208,210]$.

Induction of labour is generally possible if all the above criteria are taken into account.

\subsubsection{Special features of treatment}

Glucocorticoids are increasingly used as part of the prolongation of pregnancy according to the following treatment regimens [206, 211-214]:

- Methylprednisolone (Urbason ${ }^{\circledR}$ ) $32 \mathrm{mg} /$ day i.v. (or increased dose if necessary)

- Dexamethasone $2-3 \times 10 \mathrm{mg} /$ day i.v.

Cave: Methylprednisolone does not readily cross the placenta, therefore additional lung ripening therapy is necessary (e.g., betamethasone) [197,215-217].

In the majority of studies, glucocorticoids used ante- or postpartum resulted in clinical and biochemical remission of differing durations (the majority of studies used dexamethasone) [164, $211,213,214,219-232]$

In contrast, a placebo-controlled double-blind study found that glucocorticoids had no effect [233]. According to a Cochrane analysis, there is currently insufficient data available regarding a benefit for the fetal/maternal outcome and the uncritical use of corticosteroids is not recommended [234].

\subsubsection{Follow-up after HELLP syndrome}

HELLP syndrome is not a contraindication for further pregnancies $[159,164,189]$. Use of oral contraception is possible. The recurrence risk is increased compared to women after uncomplicated pregnancies and is between 2 and 19\% [67,159,164,187, $188,235,236]$. Early HELLP syndrome ( $<32$ weeks) appears to be accompanied by an increased risk of a recurrence of early HELLP syndrome [235]. According to a Germany-wide study, the risk of HELLP syndrome after HELLP syndrome is $12.8 \%$; the risk of other hypertensive disorders during the pregnancy is 30.4\% [67]. In subsequent pregnancies, the administration of low-dose aspirin is indicated ( $100 \mathrm{mg} /$ day) from early pregnancy. Patients should be monitored according to the criteria of a high-risk pregnancy after HELLP syndrome.

\section{Affiliations}

${ }^{1}$ Abteilung für Geburtsmedizin, Universitätsklinikum Leipzig, Leipzig

${ }^{2}$ Arbeitsgemeinschaft Gestose-Frauen e. V., Issum

${ }^{3}$ Universitätsklinikum Münster, Klinik und Poliklinik für Frauenheilkunde und Geburtshilfe, Abt. für Geburtshilfe, Münster

${ }^{4}$ Frauenklinik für Gynäkologie und Geburtshilfe, Universitätsklinikum RWTH Aachen, Aachen

${ }^{5}$ Frauenklinik Sozialstiftung Bamberg, Bamberg

${ }^{6}$ Department of Pharmacology and Therapeutics, University College Cork,

Cork, Ireland

${ }^{7}$ Klinik für Geburtsmedizin, Vivantes Klinikum Neukölln, Berlin

\section{References}

1 Lo JO, Mission JF, Caughey AB. Hypertensive disease of pregnancy and maternal mortality. Curr Opin Obstet Gynecol 2013; 25: 124-132

2 Schutte JM, Schuitemaker NW, van Roosmalen J; Dutch Maternal Mortality Committee. Substandard care in maternal mortality due to hypertensive disease in pregnancy in the Netherlands. BJOG 2008; 115 : 732-736

3 Center for Maternal and Child Enquiries (CMACE). Saving Mothers' Lives: reviewing maternal deaths to make motherhood safer: 200608. The Eighth Report on Confidential Enquiries into Maternal Deaths in the United Kingdom. BJOG 2011; 118 (Suppl. 1): 1-203

4 Kuc S, Wortelboer EJ, van Rijn BB et al. Evaluation of 7 serum biomarkers and uterine artery Doppler ultrasound for first-trimester prediction of preeclampsia: a systematic review. Obstet Gynecol Surv 2011; 66: 225-239

5 Akolekar R, Syngelaki A, Poon L et al. Competing risks model in early screening for preeclampsia by biophysical and biochemical markers. Fetal Diagn Ther 2013; 33: 8-15

6 Report of the National High Blood Pressure Education Program Working Group on High Blood Pressure in Pregnancy. Am J Obstet Gynecol 2000; 183: S1-S22

7 Brown MA, Lindheimer MD, de Swiet M et al. The classification and diagnosis of the hypertensive disorders of pregnancy: statement from the International Society for the Study of Hypertension in Pregnancy (ISSHP). Hypertens Pregnancy 2001; 20: IX-XIV

8 ACOG Committee on Obstetric Practice. ACOG practice bulletin. Diagnosis and management of preeclampsia and eclampsia. Number 33, January 2002. Int J Gynaecol Obstet 2002; 77: 67-75; Online: http://mail. ny.acog.org/website/SMIPodcast/DiagnosisMgt.pdf; last access: 01.12.2013

9 Lowe SA, Brown MA, Dekker G et al.; Society of Obstetric Medicine of Australia and New Zealand. Guidelines for the management of hypertensive disorders of pregnancy 2008. Aust N Z J Obstet Gynaecol 2009; 49: $242-246$

10 Turner JA. Diagnosis and management of pre-eclampsia: an update. Int J Womens Health 2010; 2: 327-337

11 National Collaborating Centre for Women's and Children's Health - Commissioned by the National Institute for Health and Clinical Excellence; Royal College of Obstetricians and Gynaecologists. Hypertension in pregnancy. 2011. Online: http://www.nice.org.uk/nicemedia/live/ 13098/50475/50475.pdf; last access: 01.12.2013

12 Cruz MO, Gao W, Hibbard JU. What is the optimal time for delivery in women with gestational hypertension? Am J Obstet Gynecol 2012; 207: 214.e1-214.e6

13 James JL, Whitley GS, Cartwright JE. Pre-eclampsia: fitting together the placenta, immune and cardiovascular pieces. J Pathol 2010; 221: 363378

14 Raymond $D$, Peterson E. A critical review of early-onset and late-onset preeclampsia. Obstet Gynecol Surv 2011; 66: 497-506

15 Tranquilli AL, Brown MA, Zeeman GG et al. The definition of severe and early-onset preeclampsia. Statements from the International Society for the Study of Hypertension in Pregnancy (ISSHP). Pregnancy Hypertens 2013; 3: 44-47 
16 Douglas KA, Redman KA. Eclampsia in the United Kingdom. BMJ 1994; 309: 1395-1400

17 Mattar F, Sibai BM. Eclampsia. VIII. Risk factors for maternal morbidity. Am J Obstet Gynecol 2000; 182: 307-312

18 Knight M. Eclampsia in the United Kingdom 2005. BJOG 2007; 114: 1072-1077

19 Sibai BM. Diagnosis, controversies, and management of the syndrome of hemolysis, elevated liver enzymes, and low platelet count. Obstet Gynecol 2004; 103: 981-991

20 Seely EW, Ecker J. Chronic hypertension in pregnancy. N Engl J Med 2011; 365: 439-446

21 Conde-Agudelo A, Villar J, Lindheimer M. World Health Organisation systematic review of screening tests for preeclampsia. Obstet Gynecol 2004; 104: 1367-1391

$22 \mathrm{Yu}$ CK, Smith GC, Papageorghiou AT et al. An integrated model for the prediction of pre-eclampsia using maternal factors and uterine artery Doppler velocimetry in unselected low-risk women. Am J Obstet Gynecol 2005; 193: 429-436

23 Papageorghiou AT, Leslie K. Uterine artery Doppler in the prediction of adverse pregnancy outcome. Curr Opin Obstet Gynecol 2007; 19: 103109

24 Audibert F, Boucoiran I, An N et al. Screening for preeclampsia using first-trimester serum markers and uterine artery Doppler in nulliparous women. Am J Obstet Gynecol 2010; 203: 383.e1-383.e8

25 Thilaganathan B, Wormald B, Zanardini C et al. Early-pregnancy multiple serum markers and second-trimester uterine artery Doppler in predicting preeclampsia. Obstet Gynecol 2010; 115: 1233-1238

26 Scazziocchio E, Figueras F. Contemporary prediction of preeclampsia. Curr Opin Obstet Gynecol 2011; 23: 65-71

27 Lachmann R, Schlembach D. Screening, Prädiktion und Prävention der Präeklampsie. Frauenarzt 2013; 4: 326-331

28 Akolekar R, Syngelaki A, Sarquis R et al. Prediction of early, intermediate and late pre-eclampsia from maternal factors, biophysical and biochemical markers at 11-13 weeks. Prenat Diagn 2011; 31: 66-74

29 Zhong Y, Tuuli M, Odibo AO. First-trimester assessment of placenta function and the prediction of preeclampsia and intrauterine growth restriction. Prenat Diagn 2010; 30: 293-308

30 Carbillon $L$. First trimester uterine artery Doppler for the prediction of preeclampsia and foetal growth restriction. J Matern Fetal Neonatal Med 2012; 25: 877-883

31 Kleinrouweler CE, Wiegerinck MM, Ris-Stalpers C et al.; EBM CONNECT Collaboration. Accuracy of circulating placental growth factor, vascular endothelial growth factor, soluble fms-like tyrosine kinase 1 and soluble endoglin in the prediction of pre-eclampsia: a systematic review and meta-analysis. BJOG 2012; 119: 778-787

32 Mcelrath TF, Lim KH, Pare E et al. Longitudinal evaluation of predictive value for preeclampsia of circulating angiogenic factors through pregnancy. Am J Obstet Gynecol 2012; 207: 407.e1-407.e7

33 Melchiorre K, Wormald B, Leslie $\mathrm{K}$ et al. First-trimester uterine artery Doppler indices in term and preterm pre-eclampsia. Ultrasound Obstet Gynecol 2008; 32: 133-137

34 Bahado-Singh RO, Jodicke C. Uterine artery Doppler in first-trimester pregnancy screening. Clin Obstet Gynecol 2010; 53: 879-887

35 Scazzocchio E, Figueras F, Crispi F et al. Performance of a first-trimester screening of preeclampsia in a routine care low-risk setting. Am J Obstet Gynecol 2013; 208: 203.e1-203.e10

36 Poon LC, Syngelaki A, Akolekar R et al. Combined screening for preeclampsia and small for gestational age at 11-13 weeks. Fet Diagn Ther 2013; 13: 16-27

37 Myatt L, Clifton RG, Roberts JM et al.; Eunice Kennedy Shriver National Institute of Child Health and Human Development (NICHD) Maternal-Fetal Medicine Units (MFMU) Network. First-trimester prediction of preeclampsia in nulliparous women at low risk. Obstet Gynecol 2012; 119: $1234-1242$

38 Papageorghiou AT, Yu CK, Bindra R et al.; Fetal Medicine Foundation Second Trimester Screening Group. Multicenter screening for pre-eclampsia and fetal growth restriction by transvaginal uterine artery Doppler at 23 weeks of gestation. Ultrasound Obstet Gynecol 2001; 18: 441449

39 Cnossen JS, Morris RK, ter Riet G et al. Use of uterine artery Doppler ultrasonography to predict pre-eclampsia and intrauterine growth restriction: a systematic review and bivariable meta-analysis. CMAJ 2008; 178: 701-711

$40 \mathrm{Yu}$ CK, Khouri O, Onwudiwe $\mathrm{N}$ et al. Prediction of pre-eclampsia by uterine artery Doppler imaging: relationship to gestational age at delivery and small-for-gestational age. Ultrasound Obstet Gynecol 2008; 31: 310-313

41 Phupong V, Dejthevaporn T. Predicting risks of preeclampsia and small for gestational age infant by uterine artery Doppler. Hypertens Pregnancy 2008; 27: 387-395

42 Cooper S, Johnson JA, Metcalfe A et al. The predictive value of 18-22 week uterine artery Doppler in patients with low first trimester maternal serum PAPP-A. Prenat Diagn 2009; 29: 248-252

43 Stepan $H$, Unversucht A, Wessel $N$ et al. Predictive value of maternal angiogenic factors in second trimester pregnancies with abnormal uterine perfusion. Hypertension 2007; 49: 818-824

44 Spencer K, Yu CK, Savvidou M et al. Prediction of pre-eclampsia by uterine artery Doppler ultrasonography and maternal serum pregnancyassociated plasma protein-A, free beta-human chorionic gonadotropin, activin A and inhibin A at $22+0$ to $24+6$ weeks' gestation. Ultrasound Obstet Gynecol 2006; 27: 658-663

45 Gómez-Arriaga PI, Herraiz I, López-Jiménez EA et al. Uterine artery Doppler and sFlt-1/PIGF ratio: usefulness in diagnosis of pre-eclampsia. Ultrasound Obstet Gynecol 2013; 41: 530-537

46 Levine RJ, Lam C, Quian C et al.; for the CPEP Study Group. Soluble endoglin and other circulating antiangiogenic factors in preeclampsia. New Engl J Med 2006; 355: 992-1005

47 Crispi F, Domínguez C, Llurba E et al. Placental angiogenic growth factors and uterine artery Doppler findings for characterization of different subsets in preeclampsia and isolated intrauterine growth restriction. Am J Obstet Gynecol 2006; 195: 201-207

48 Crispi F, Llurba E, Domínguez C et al. Predictive value of angiogenic factors and uterine artery Doppler for early- versus late-onset pre-eclampsia and intrauterine growth restriction. Ultrasound Obstet Gynecol 2008; 31: 303-309

49 Verlohren S, Galindo A, Schlembach $D$ et al. An automated method for the determination of the sFlt-1/PIGF ratio in the assessment of preeclampsia. Am J Obstet Gynecol 2010; 202: 161.e1-161.e11

50 Verlohren S, Herraiz I, Lapaire $O$ et al. The sFlt-1/PIGF ratio in different types of hypertensive pregnancy disorders and its prognostic potential in preeclamptic patients. Am J Obstet Gynecol 2012; 206: 58.e1-58.e8

51 Bujold E, Roberge S, Lacasse Y et al. Prevention of preeclampsia and intrauterine growth restriction with aspirin started in early pregnancy: a meta-analysis. Obstet Gynecol 2010; 116 (2 Pt 1): 402-414

52 Roberge S, Villa P, Nicolaides $K$ et al. Early administration of low-dose aspirin for the prevention of preterm and term preeclampsia: a systematic review and meta-analysis. Fetal Diagn Ther 2012; 31: 141-146

53 Bujold E, Morency AM, Roberge S et al. Acetylsalicylic acid for the prevention or preeclampsia and intra-uterine growth restriction in women with abnormal uterine artery Doppler: a systematic review and meta-analysis. J Obstet Gynecol Can 2009; 31: 818-826

54 Murakami S, Saitoh M, Kubo T et al. Renal disease in women with severe preeclampsia or gestational proteinuria. Obstet Gynecol 2000; 96: 945-949

55 Stamilio DM, Sehdev HM, Morgan MA et al. Can antenatal clinical and biochemical markers predict the development of severe preeclampsia? Am J Obstet Gynecol 2000; 182: 589-594

56 Dekker G, Sibai B. Primary, and tertiary prevention of preeclampsia. Lancet 2001; 357: 209-215

57 Julkunen H. Pregnancy and lupus nephritis. Scand J Urol Nephrol 2001; 35: $319-327$

58 Erkan D, Sammaritano $L$. New insights into pregnancy-related complications in systemic lupus erythematosus. Curr Rheumatol Rev 2003; 5: 357-363

59 Duckitt K, Harrington D. Risk factors for pre-eclampsia at antenatal booking: systematic review of controlled studies. BMJ 2005; 330: 565

60 Chappell LC, Enye S, Seed P et al. Adverse perinatal outcomes and risk factors for preeclampsia in women with chronic hypertension: a prospective study. Hypertension 2008; 51: 1002-1009

61 Trogstad L, Magnus P, Stoltenberg C. Pre-eclampsia: risk factors and causal models. Best Pract Res Clin Obstet Gynaecol 2011; 25: 329-342

62 Pecks U, Maass N, Neulen J. Oocyte donation: a risk factor for pregnancy-induced hypertension: a meta-analysis and case series. Dtsch Arztebl Int 2011; 108: 23-31

63 Barton JR, Sibai BM. Prediction and prevention of recurrent preeclampsia. Am J Obstet Gynceol 2008; 112 (2 Pt 1): 359-372

64 Brown MA, Mackenzie C, Dunsmuir W et al. Can we predict recurrence of pre-eclampsia or gestational hypertension? BJOG 2007; 114: 984 993 
65 Mostello D, Kallogjeri D, Tungsiripat R et al. Recurrence of preeclampsia: effects of gestational age at delivery of the first pregnancy, body mass index, paternity, and interval between births. Am J Obstet Gynecol 2008; 199: 55.e1-55.e7

66 Hernández-Diaz S, Toh S, Cnattingius S. Risk of pre-eclampsia in first and subsequent pregnancies: prospective cohort study. BMJ 2009; 338: b2255

67 Leeners B, Neumaier-Wagner PM, Kuse S et al. Recurrence risk of hypertensive disease in pregnancy after HELLP syndrome. J Perinat Med 2011; 39: 673-678

68 Sibai BM. Diagnosis, prevention, and management of eclampsia. Obstet Gynecol 2005; 105: 402-410

69 Shennan A, Gupta M, Halligan A et al. Lack of reproducibility in pregnancy of Korotkoff phase IV as measured by mercury sphygmomanometry. Lancet 1996; 347: 139-142

70 Brown MA, Buddle ML, Farrell T et al. Randomised trial of management of hypertensive pregnancies by Korotkoff phase IV or phase V. Lancet 1998; 352: 777-781

71 Bergert FW, Braun M, Clarius H et al. Hausärztliche Leitlinie Hypertonie - Therapie der Hypertonie. 2010. Online: http://www.pmvforschungsgruppe.de/pdf/03_publikationen/hypertonie_ll.pdf; last access: 01.12.2013

72 Pettit F, Brown MA. The management of pre-eclampsia: what we think we know. Eur J Obstet Gynecol Reprod Biol 2012; 160: 6-12

73 Brown MA, Mangos G, Davis G et al. The natural history of white coat hypertension during pregnancy. BJOG 2005; 112: 601-606

74 Villar J, Say L, Shennan A et al. Methodological and technical issues related to the diagnosis, screening, prevention, and treatment of pre-eclampsia and aclampsia. Int J Gynaecol Obstet 2004; 85 (Suppl. 1): S28S41

75 Chung Y, de Greeff A, Shennan A. Validation and compliance of a home monitoring device in pregnancy: microlife WatchBP home. Hypertens Pregnancy 2009; 28: 348-359

76 Waugh JJ, Bell SC, Kilby MD et al. Optimal bedside urinanalysis for the detection of proteinuria in hypertensive pregnancy: a study of diagnostic accuracy. BJOG 2005; 112: 412-417

77 Gangaram R, Ojwang PJ, Moodley J et al. The accuracy of uterine dipsticks as a screening test for proteinuria in hypertensive disorders of pregnancy. Hypertens Pregnancy 2005; 24: 117-123

78 Lindheimer MD, Kanter D. Interpreting abnormal proteinuria in pregnancy. Obstet Gynecol 2010; 115: 365-375

79 Airoldi $K$, Weinstein L. Clinical significance of proteinuria in pregnancy. Obstet Gynecol Surv 2007; 62: 117-124

80 Côté AM, Brown MA, Lam E et al. Diagnostic accuracy of urinary spot protein:creatinine ratio for proteinuria in hypertensive pregnant women: systematic review. BMJ 2008; 336: 1003-1006

81 Yamasmit W, Chaithongwongwatthana S, Charoenvidhya D et al. Random urinary protein-to-creatinine ratio for prediction of significant proteinuria in women with preeclampsia. J Matern Fetal Neonatal Med 2004; 16: 275-279

82 Wiwanikit $V$. Periodic urinary protein creatinine ratio for predicting significant proteinuria in preeclampsia in different alternatives: time effectiveness analysis. Arch Gynecol Obstet 2010; 281: 571-573

83 Morris RK, Riley RD, Doug $M$ et al. Diagnostic accuracy of spot urinary protein and albumin to creatinine ratios for detection of significant proteinuria or adverse pregnancy outcome in patients with suspected pre-eclampsia: systematic review and meta-analysis. BMJ 2012; 345: e4342

84 Chen BA, Parviainen K, Jeyabalan A. Correlation of catheterized and clean catch urine protein/creatinine ratios in preeclampsia evaluation. Obstet Gynecol 2008; 112: 606-610

85 Phelan $L K$, Brown MA, Davis GK et al. A prospective study of the impact of automated dipstick urinalysis on the diagnosis of preeclampsia. Hypertens Pregnancy 2004; 23: 135-142

86 Ochsenbein-Kölble N, Roos M, Gasser $T$ et al. Cross-sectional study of weight gain and increase in BMI throughout pregnancy. Eur J Obstet Gynaecol Reprod Biol 2007; 130: 180-186

87 Thangaratinam S, Koopmans CM, Iyengar S et al.; TIPPS (Test in Prediction of Preeclampsia's Severity) Review Group. Accuracy of liver function test for predicting adverse maternal and fetal outcomes in women with preeclampsia: a systematic review. Acta Obstet Gynecol Scan 2011; 90: 574-585

88 Ghosh SK, Raheja S, Tull A et al. Serum PIGF as a potential biomarker for predicting the onset of preeclampsia. Arch Gynecol Obstet 2012; 285: $417-422$
89 Hawkins TL, Roberts JM, Mangos GJ et al. Plasma uric acid remains a marker of poor outcome in hypertensive pregnancy: a retrospective cohort study. BJOG 2012; 119: 484-492

90 Sibiude J, Guibourdenche J, Dionne MD et al. Placental growth factor for the prediction of adverse outcomes in patients with suspected preeclampsia or intrauterine growth restriction. PLoS One 2012; 7: e50208

91 Rana S, Powe CE, Salahuddin $S$ et al. Angiogenic factors and the risk of adverse outcomes in women with suspected preeclampsia. Circulation 2012; 125: 911-919

92 Milne F, Redman C, Walker J et al. The pre-eclampsia community guideline (PRECOG): how to screen for and detect onset of pre-eclampsia in the community. BMJ 2005; 330: 576-580

93 Rath W. Hypertensive Schwangerschaftserkrankungen. Der Gynäkologe 1999; 32: 432-442

94 Thangaratinam S, Gallos ID, Meah $N$ et al.; TIPPS (Tests in Prediction of Pre-eclampsia's Severity) Review Group. Acta Obstet Gynceol Scand 2011; 90: 564-573

95 Abalos E, Duley L, Steyn DW et al. Antihypertensive drug therapy for mild to moderate hypertension during pregnancy. Cochrane Database Syst Rev 2007; 1: CD002252

96 Redman CW, Roberts JM. Management of pre-eclampsia. Lancet 1993; 341: 1451-1454

97 Sibai BM. Treatment of hypertension in pregnant women. N Engl J Med 1996; 335: 257-265

98 Coetzee EJ, Dommisse J, Anthony J. A randomised controlled trial of intravenous magnesium sulphate versus placebo in the management of women with severe pre-eclampsia. Br J Obstet Gynaecol 1998; 105: 300-303

99 Altman D, Carroli D, Duley L et al.; Magpie Trial Collaboration Group. Do women woth pre-eclampsia, an their babies, benefit from magnesium suplhate? The MagPie Trial: a randomised placebo-controlled trial. Lancet 2002; 359: 1877-1890

100 Sibai B, Dekker G, Kupferminc M. Pre-eclampsia. Lancet 2005; 365: 785-799

101 Steegers EA, van Dadelszen P, Duvekot JJ et al. Pre-eclampsia. Lancet 2010; 376: 631-644

102 Magee LA, Abalos E, von Dadelszen P et al.; CHIPS Study Group. How to manage hypertension in pregnancy effectively. $\mathrm{Br} \mathrm{J}$ Clin Pharmacol 2011; 72: 394-401

103 Schaefer C, Spielmann H, Vetter K. Arzneimittel in Schwangerschaft und Stillzeit. 8. Aufl. München: Verlag Urban \& Fischer; 2012

104 Committee on Obstetric Practice. Committe Opinion no. 514: emergent therapy for acute-onset, severe hypertension with preeclampsia or eclampisa. Obstet Gynecol 2011; 118: 1465-1468

105 Leveno KJ, Cunningham FG. Management of Preeclampsia. In: Lindheimer MD, Roberts JM, Cunningham FG, eds. Chesley's hypertensive Disorders in Pregnancy. Stamford, Connecticut: Appleton \& Lange; 1999: 543-580

106 Behandlung der hypertensiven Krise. Arznei-Telegramm 1999; 1: 2-5

107 Van den Born BJ, Beutler JJ, Gaillard CA et al. Dutch guideline for the management of hypertensive crisis - 2010 revision. Neth J Med 2011; 69: 248-255

108 Wacker JR, Wagner BK, Briese V et al. Antihypertensive therapy in patients with preeclampsia: a prospective randomised multicentre study comparing dihydralazine with urapidil. Eur J Obstet Gynecol Reprod Med 2006; 127: 160-165

109 Carles G, Helou J, Dallah F et al. Use of injectable urapidil in pregnancy-induced hypertension and preeclampsia. J Gynecol Obstet Biol Reprod 2012; 41: 645-649

110 Magee LA, Cham C, Waterman EJ et al. Hydralazine for treatment of severe hypertension in pregnancy: meta-analysis. BMJ 2003; 327: 955-960

111 Duley L, Henderson-Smart DJ, Meher S. Drugs for treatment of very high blood pressure during pregnancy. Cochrane Database Syst Rev 2006; 3: CD001449

112 Duley L, Henderson-Smart DJ, Walker GJ et al. Magnesium sulphate versus diazepam for eclampsia. Cochrane Database Syst Rev 2010; 12: CD000127

113 Duley L, Gülmezoglu AM, Henderson-Smart DJ et al. Magnesium sulphate and other anticonvulsants for women with pre-eclampsia. Cochrane Database Syst Rev 2010; 11: CD000025

114 Duley L, Henderson-Smart DJ, Chou D. Magnesium sulphate versus phenytoin for eclampsia. Cochrane Database Syst Rev 2010; 10 : CD000128 
115 Duley L, Gülmezoglu AM, Chou D. Magnesium sulphate versus lytic cocktail for eclampsia. Cochrane Database Syst Rev 2010; 9: CD002960

116 Duley L. Pre-eclampsia, eclampsia, and hypertension. BMJ Clin Evid 2011; 2011: pii: 1402

117 Magpie Trial Follow-Up Study Collaborative Group. The Magpie Trial: a randomised trial comparing magnesium sulphate with placebo for pre-eclampsia. Outcome for women at 2 years. BJOG 2007; 114: 300-309

118 Magpie Trial Follow-Up Study Collaborative Group. The Magpie Trial: a randomised trial comparing magnesium sulphate with placebo for pre-eclampsia. Outcome for children at 18 months. BJOG 2007; 114: 289-299

119 Which anticonvulsant for women with eclampsia? Evidence from the Collaborative Eclampsia Trial. Lancet 1995; 345: 1455-1463

120 Duley L, Matar HE, Almerie MQ et al. Alternative magnesium sulphate regimens for women with pre-eclampsia and eclampsia. Cochrane Database Syst Rev 2010; 8: CD007388

121 Duley L, Williams J, Henderson-Smart DJ. Plasma volume expansion for treatment of women with pre-eclampsia. Cochrane Database Syst Rev 2000; 2: CD001805

122 Ganzevoort W, Rep A, Bonsel GJ et al.; PETRA investigators. A randomised controlled trial comparing two temporising management strategies, one with and one without plasma volume expansion, for severe and early onset pre-eclampsia. BJOG 2005; 112: 1358-1368

123 Koopmans CM, Bijlenga D, Groen $H$ et al.; HYPITAT study group. Induction of labour versus expectant monitoring for gestational hypertension or mild pre-eclampsia after 36 weeks' gestation (HYPITAT): a multicentre, open-label randomised controlled trial. Lancet 2009; 374: 979-988

124 Alfirevic Z, Neilson JP. Doppler ultrasonography in high-risk pregnancies: systematic review with meta-analysis. Am J Obstet Gynecol 1995; 172: 1379-1387

125 Westergaard HB, Langhoff-Roos J, Lingman G et al. A critical appraisal of the use of umbilical artery Doppler ultrasound in high-risk pregnancies: use of meta-analyses in evidence-based obstetrics. Ultrasound Obstet Gynecol 2001; 17: 466-476

126 Baschat AA. Pathophysiology of fetal growth restriction: implications for diagnosis and surveillance. Obstet Gynecol Surv 2004; 59: $617-$ 627

127 Marsal K. Obstetric management of intrauterine growth restriction. Best Pract Res Clin Obstet Gynaecol 2009; 23: 857-870

128 Alfirevic Z, Stampalija T, Gyte GM. Fetal and umbilical Doppler ultrasound in high risk pregnancies. Cochrane Database Syst Rev 2010; 1: CD007529

129 Maulik D, Mundy D, Heitmann E et al. Evidence-based approach to umbilical artery Doppler fetal surveillance in high-risk pregnancies: an update. Clin Obstet Gynecol 2010; 53: 869-878

130 Galan HL. Timing delivery of the growth restricted fetus. Semin Perinatol 2011; 35: 262-269

131 Morris RK, Malin G, Robson SC et al. Fetal umbilical artery Doppler to predict compromise of fetal/neonatal wellbeing in a high-risk population: systematic review and bivariate meta-analysis. Ultrasound Obstet Gynecol 2011; 37: 135-142

132 Schlembach $D$. Intrauterine Wachstumsrestriktion - Diagnostik und Management. Geburtsh Frauenheilk 2012; 72: 373-375

133 Magann EF, Chauhan SP, Kinsella MJ et al. Antenatal testing among 1001 patients at high risk: the role of ultrasonographic estimate of amniotic fluid volume. Am J Obstet Gynecol 1999; 180: 1330-1336

134 Hashimoto $K$, Kasdaglis T, Jain $S$ et al. Isolated low-normal amniotic fluid volume in the early third-trimester: association with adverse perinatal outcomes. J Perinat Med 2013; 41: 349-353

135 Backes CH, Marham K, Moorehead P et al. Maternal preeclampsia and neonatal outcomes. J Pregnancy 2011; 2011: 2141365

136 Reddy UM, Bettegowda VR, Dias T et al. Term pregnancy: a period of heterogeneous risk for infant mortality. Obstet Gynecol 2011; 117: $1279-1287$

137 Khashu M, Narayanan M, Bhargava S et al. Perinatal outcomes associated with preterm birth at 33 to 36 week's gestation: a populationbased cohort study. Pediatrics 2009; 123: 109-113

138 Simpson $L L$. Maternal medical disease: risk of antepartum fetal death. Semin Perinatol 2002; 26: 42-50

139 Odegård RA, Vatten LJ, Nilsen ST et al. Preeclampsia and fetal growth. Obstet Gynecol 2000; 96: 950-955
140 Odendaal HJ, Pattinson RC, Bam R et al. Aggressive or expectant management for patients with severe preeclampsia between 28-34 weeks' gestation: a randomized controlled trial. Obstet Gynecol 1990; 76: 1070-1075

141 Sibai BM, Mercer BM, Schiff E et al. Aggressive versus expectant management of severe pre-eclampsia at 28 to 32 weeks' gestation: a randomized controlled trial. Am J Obstet Gynecol 1994; 171: 818-822

142 Haddad B, Deis S, Goffinet F et al. Maternal and perinatal outcomes during expectant management of 239 severe preeclamptic women between 24 and 33 weeks' gestation. Am J Obstet Gynecol 2004; 190: 1590-1597

143 Visser $W$, Wallenburg HC. Temporising management of severe pre-eclampsia with and without the HELLP syndrome. Br J Obstet Gynaecol 1995; 102: 111-117

144 Abramovici D, Friedman SA, Mercer BM et al. Neonatal outcome in severe preeclampsia at 24 to 36 weeks' gestation: does the HELLP (hemolysis, elevated liver enzymes, and low platelet count) syndrome matter? Am J Obstet Gynecol 1999; 180: 221-225

145 Shear RM, Rinfret D, Leduc L. Should we offer expectant management in cases of severe preterm preeclampsia with fetal growth restriction? Am J Obstet Gynecol 2005; 192: 1119-1125

146 Sibai BM; Publications Committee; Society for Maternal-Fetal Medicine. Evaluation and management of severe preeclampsia before 34 weeks' gestation. Am J Obstet Gynecol 2011; 205: 191-198

147 Sibai BM, Akl S, Fairlie F et al. A protocol for managing severe preeclampsia in the second trimester. Am J Obstet Gynecol 1990; 163: 733-738

148 Gaugler-Senden IP, Huijssoon AG, Visser W et al. Maternal and perinatal outcome of preeclampsia with an onset before 24 weeks' gestation. Audit in a tertiary referral center. Eur J Obstet Gynecol Reprod Biol 2006; 128: 216-221

149 Bombrys AE, Barton JR, Nowacki EA et al. Expectant management of severe preeclampsia at less than 27 weeks' gestation: maternal and perinatal outcomes according to gestational age by weeks at onset of expectant management. Am J Obstet Gynecol 2008; 199: 247.e1-247. e6

150 Nassar AH, Adra AM, Chakhtoura N et al. Severe preeclampsia remote from term: labor induction or elective cesarean delivery? Am J Obstet Gynecol 1998; 179: 1210-1213

151 Rath W. Hypertensive Schwangerschaftserkrankungen. In: Rath W, Friese K, Hrsg. Erkrankungen in der Schwangerschaft. Stuttgart, New York: Thieme; 2005: 73-97

152 Seal SL, Gosh D, Kamilya $G$ et al. Does route of delivery affect maternal and perinatal outcome in women with eclampsia? A randomized controlled pilot study. Am J Obstet Gynecol 2012; 206: 484.e1-484.e7

153 Sibai BM, Ramadan MK, Usta I et al. Maternal morbidity and mortality in 442 pregnancies with hemolysis, elevated liver enzymes, and low platelets (HELLP syndrome). Am J Obstet Gynecol 1993; 169: 10001006

154 Sanner B. Richtig Blutdruck messen. Druckpunkt 2008; 3: 14-17: Online: http://www.hochdruckliga.de/richtig-blutdruck-messen.html; last access: 01.12.2013

155 Haller H. Leitlinien zur Diagnostik und Therapie der arteriellen Hypertonie. Druckpunkt 2007; 3: 16-18; http://www.hochdruckliga. de/leitlinien-zur-diagnostik-und-therapie-der-arteriellenhypertonie.html; last access: 01.12.2013

156 AWMF-Leitlinie 046/001: Leitlinien zur Behandlung der arteriellen Hypertonie. Online: http://www.awmf.org/uploads/tx_szleitlinien/ 046-001_S2_Behandlung_der_arteriellen_ Hypertonie_06-2008_06-2013.pdf; last access: 01.12.2013

157 Leeners B, Rath W, Kuse S et al. Satisfaction with medical information in women with hypertensive disorders in pregnancy. J Psychosom Res 2006; 60: 39-44

158 Leeners B, Neumaier-Wagner P, Kuse S et al. Emotional stress and the risk to develop hypertensive diseases in pregnancy. Hypertens Pregnancy 2007; 26: 211-226

159 Sibai BM, Ramadan MK, Chari RS et al. Pregnancies complicated by HELLP syndrome (hemolysis, elevated liver enzymes, and low platelets): subsequent pregnancy outcome and long-term prognosis. Am J Obstet Gynecol 1995; 172 (1 Pt 1): 125-129

160 Nagai Y, Arai H, Washizawa Y et al. FSGS-like lesions in pre-eclampsia. Clin Nephrol 1991; 36: 134-140

161 Nisell H, Lintu H, Lunell NO et al. Blood pressure and renal function seven years after pregnancy complicated by hypertension. $\mathrm{Br}$ J Obstet Gynaecol 1995; 102: 876-881 
162 Pourrat 0 , Pierre F. [Medical assessment after a pre-eclampsia: why? for whom? when? how? for what purpose?]. Rev Med Interne 2010; 31: 766-771

163 Spaan JJ, Ekhart T, Spaanderman ME et al. Renal function after preeclampsia: a longitudinal pilot study. Nephron Clin Pract 2012; 120 : c156-c161

164 Haram K, Svendsen E, Abildgaard U. The HELLP syndrome: clinical issues and management. A Review. BMC Pregnancy Childbirth 2009; 9:

165 Sibai BM, el-Nazer A, Gonzalez-Ruiz A. Severe preeclampsia-eclampsia in young primigravid women: subsequent pregnancy outcome and remote prognosis. Am J Obstet Gynecol 1986; 155: 1011-1016

166 Van Assche FA, Holemans K, Aerts L. Fetal growth and consequences for later life. J Perinat Med 1998; 26: 337-346

167 Irgens HU, Reisaeter L, Irgens LM et al. Long term mortality of mothers and fathers after pre-eclampsia: population based cohort study. BMJ 2001; 323: 1213-1217

168 Sattar N, Greer IA. Pregnancy complications and maternal cardiovascuar risk: opportunities for intervention and prevention. BMJ 2002; 325: $157-160$

169 Wilson BJ, Watson MS, Prescott GJ et al. Hypertensive diseases of pregnancy and risk of hypertension and stroke in later life: results from cohort study. BMJ 2003; 326: 845-851

170 Roberts JM, Gammill H. Pre-eclampsia and cardiovascular disease in later life. Lancet 2005; 366: 961-962

171 Anderson CM. Preeclampsia: exposing future cardiovascular risk in mothers and their children. J Obstet Gynecol Neonatal Nurs 2007; 36: 3-8

172 Newstead J, von Dadelszen P, Magee LA. Preeclampsia and future cardiovascular risk. Expert Rev Cardiovasc Ther 2007; 5: 283-294

173 Suzuki $\mathrm{H}$, Watanabe Y, Arima $\mathrm{H}$ et al. Short- and long-term prognosis of blood pressure and kidney disease in women with a past history of preeclampsia. Clin Exp Nephrol 2008; 12: 102-109

174 Lykke JA, Langhoff-Roos J, Sibai BM et al. Hypertensive pregnancy disorders and subsequent cardiovascular morbidity and type 2 diabetes mellitus in the mother. Hypertension 2009; 53: 944-951

175 Iversen L, Hannaford PC. Toxaemia of pregnancy and risk of mortality in later life: evidence from the Royal College of General Practitioners' Oral Contraception Study. Hypertens Pregnancy 2010; 29: 180-197

176 Lykke JA, Langhoff-Roos J, Lockwood CJ et al. Mortality of mothers from cardiovascular and non-cardiovascular causes following pregnancy complications in first delivery. Pediatr Perinat Epidemiol 2010; 24: 323-330

177 Díaz-Martínez LA, Día Pedraza Ndel M, Serrano Díaz NC et al. [The prognosis for children of mothers with preeclampsia. Part 2: longterm effects]. Arch Argent Pediatr 2011; 109: 519-524

178 Davis EF, Lazdam M, Lewandowksi AJ et al. Cardiovascular risk factors in children and young adults born to preeclamptic pregnancies: a systematic review. Pediatrics 2012; 129: e1552-e1561

179 Mangos GJ, Spaan JJ, Pirabhahar S et al. Markers of cardiovascular disease after hypertension in pregnancy. J Hypertens 2012; 30: 351-358

180 Smith GN, Pudwell J, Walker M et al. Ten-year, thirty-year, and lifetime cardiovascular disease risk estimates following a pregnancy complicated by preeclampsia. J Obstet Gynaecol Can 2012; 34: 830-835

181 Brown MC, Best KE, Pearce MS et al. Cardiovascular disease risk in women with pre-eclampsia: systematic review and meta-analysis. Eur J Epidemiol 2013; 28: 1-19

182 Brown MC, Bell R, Collins C et al. Women's perception of future risk following pregnancies complicated by preeclampsia. Hypertens Pregnancy 2013; 32: 60-73

183 Heidrich MB, Wenzel D, von Kaisenberg CS et al. Preeclampsia and long-term risk of cardiovascular disease: what do obstetrician-gynecologists know? BMC Pregnancy Childbirth 2013; 13: 61

184 Sibai BM, Mercer B, Sarinoglu C. Severe preeclampsia in the second trimester: recurrence risk and long-term prognosis. Am J Obstet Gynecol 1991; 165 (5 Pt 1): 1408-1412

185 Dukler D, Porath A, Bashiri A et al. Remote prognosis of primiparous women with preeclampsia. Eur J Obstet Gynecol Reprod Biol 2001; 96: 69-74

186 Van Rijn BB, Hoeks LB, Bots ML et al. Outcomes of subsequent pregnancy after first pregnancy with early-onset preeclampsia Am J Obstet Gynecol 2006; 195: 723-728

187 Langenveld J, Jansen S, van der Post J et al. Recurrence risk of a delivery before 34 weeks of pregnancy due to an early onset hypertensive disorder: a systemativ review. Am J Perinatol 2010; 27: 565-571
188 Langenveld J, Buttinger A, van der Post J et al. Recurrence risk and prediction of a delivery under 34 weeks of gestation after a history of a severe hypertensive disorder. BJOG 2011; 118: 589-595

189 Fischer T, Langenfeld M. Nachbetreuung von Präeklampsie-Patientinnen. In: Heilmann L, Rath W, Hrsg. Schwangerschaftshochdruck. Stuttgart: Wissenschaftliche Verlagsgesellschaft; 2002: 279-296

190 Fischer T, Pildner von Steinburg S, Diedrich F et al. Prävention der Präeklampsie. Zentralbl Gynakol 2005; 127: 83-90

191 Weinstein L. Syndrome of hemolysis, elevated liver enzymes, and low platelet count: a severe consequence of hypertension in pregnancy. Am J Obstet Gynaecol 1982; 142: 159-167

192 Rath W, Loos W, Graeff H et al. Das HELLP-Syndrom. Der Gynäkologe 1992; 25: 430-440

193 Rath W, Faridi A, Dudenhausen JW. HELLP syndrome. J Perinat Med 2000; 28: 249-260

194 Marchand A, Galen RS, Van LF. The predictive value of serum haptoglobin in hemolytic disease. JAMA 1980; 243: 1909-1911

195 Poldre PA. Haptoglobin helps diagnose the HELLP syndrome. Am J Obstet Gynecol 1987; 157: 1267

196 Wilke G, Rath W, Schutz E et al. Haptoglobin as a sensitive marker of hemolysis in HELLP syndrome. Int J Gynecol Obstet 1992; 39: 29-34

197 Van Runnard Heimel PJ, Franx A, Schobben AF et al. Corticosteroids, pregnancy, and HELLP syndrome: a review. Obstet Gynecol Surv 2005; 60: $57-70$

198 Deruelle P, Coudoux E, Ego A et al. Risk factors for post-partum complications occurring after preeclampsia and HELLP syndrome. A study in 453 consecutive pregnancies. Eur J Obstet Gynecol Reprod Biol 2006; 125: 59-65

199 Van Runnard Heimel PJ, Kavelaars A, Heijnen CJ et al. HELLP syndrome is associated with an increased inflammatory response, which may be inhibited by administration of prednisolone. Hypertens Pregnancy 2008;27: 253-265

200 Martin JN jr., May WL, Magann EF et al. Early risk assessment of severe preeclampsia: admission battery of symptoms and laboratory tests to predict likelihood of subsequent significant maternal morbidity. Am J Ostet Gynecol 1999; 180: 1407-1414

201 Hackenberg H, Rappe N, Wohlers S et al. Wertigkeit des C-reaktiven Proteins (CRP) beim HELLP-Syndrom. Geburtsh Frauenheilk 1998; 58: 508-512

202 Paternoster DM, Fantinato S, Stella A et al. C-reactive protein in hypertensive disorders in pregnancy. Clin Appl Thromb Hemost 2006; 12: 330-337

203 Molvarec A, Prohászka Z, Nagy B et al. Association of increased serum heat shock protein 70 and C-reactive protein concentrations and decreased serum alpha(2)-HS glycoprotein concentration with the syndrome of hemolysis, elevated liver enzymes, and low platelet count. J Reprod Immunol 2007; 73: 172-179

204 Pawelec M, Palczynski B, Karmowski A. HELLP syndrome in pregnancies below 26th week. J Matern Fetal Neonatal Med 2012; 25: 467470

205 Reimer T, Rohrmann H, Stubert J et al. Angiogenic factors and acutephase proteins in serum samples of preeclampsia and HELLP patients: a matched-pair analysis. J Matern Fetal Neonatal Med 2013; 26: $263-269$

206 Martin JN jr., Rose CH, Briery CM. Understanding and managing HELLP syndrome: the integral role of aggressive glucocorticoids for mother and child. Am J Obstet Gynecol 2006; 195: 914-934

207 Fischer T, Wildt L. Glukokortikoide und HELLP-Syndrom. Der Gynäkologe 1999; 32: 783-790

208 Rath W, Bartz C. Therapeutisches Vorgehen bei schwerer Präeklampsie und beim HELLP-Syndrom. Zentralbl Gynakol 2004; 126: 293-298

209 Gul A, Cebeci A, Aslan H et al. Perinatal outcomes in severe preeclampsia-eclampsia with and without HELLP syndrome. Gynecol Obstet Invest 2005; 59: 113-118

210 Bartz C, Rath W. Aktuelles Management beim HELLP-Syndrom. Gynäkol Gebursthilfliche Rundsch 2007; 47: 215-221

211 Magann EF, Bass D, Chauhan SP et al. Antepartum corticosteroids: disease stabilization in patients with the syndrome of hemolysis, elevated liver enzymes, and low platelets (HELLP). Am J Obstet Gynecol 1994; 171: 1148-1153

212 Van Pampus MG, Wolf H, Westenberg SM et al. Maternal and perinatal outcome after expectant management of the HELLP syndrome compared with pre-eclampsia without HELLP syndrome. Eur J Obstet Gynecol Reprod Biol 1998; 76: 31-36 
213 Fischer T, Krause M, Beinder E et al. Schwangerschaftsverlängerung bei Patientinnen mit HELLP-Syndrom. Geburtsh Frauenheilk 1999; 59: 335-345

214 van Runnard Heimel PJ, Huisjes AJ, Franx A et al. A randomised placebo-controlled trial of prolonged prednisolone administration to patients with HELLP syndrome remote from term. Eur J Obstet Gynecol Reprod Biol 2006; 128: 187-193

215 Beitins IZ, Bayard F, Ances IG et al. The transplacental passage of prednisone and prednisolone in pregnancy near term. J Pediatr 1972; 81: 936-945

216 Blanford AT, Murphy BE. In vitro metabolism of prednisolone, dexamethasone, betamethasone, and cortisol by the human placenta. Am J Obstet Gynecol 1977; 127: 264-267

217 Ballard PL, Granberg P, Ballard RA. Glucocorticoid levels in maternal and cord serum after prenatal betamethasone therapy to prevent respiratory distress syndrome. J Clin Invest 1975; 56: 1548-1554

218 O'Brien JM, Miligan DA, Barton JR. Impact of high-dose corticosteroid therapy for patients with HELLP (hemolysis, elevated liver enzymes, and low platelet count) syndrome. Am J Obstet Gynecol 2000; 183: 921-924

219 Magann EF, Perry KG jr., Meydrech EF et al. Postpartum corticosteroids: accelerated recovery from the syndrome of hemolysis, elevated liver enzymes, and low platelets (HELLP). Am J Obstet Gynecol 1994; 171: $1154-1158$

220 Vigil-De Gracia P, García-Cáceres E. Dexamethasone in the post-partum treatment of HELLP syndrome. Int J Gynaecol Obstet 1997; 59: 217-221

221 Yalcin OT, Sener T, Hassa H et al. Effects of postpartum corticosteroids in patients with HELLP syndrome. Int J Gynaecol Obstet 1998; 61: 141-148

222 Martin JN jr., Perry KG jr., Blake PG et al. Better maternal outcomes are achieved with dexamethasone therapy for postpartum HELLP (hemolysis, elevated liver enzymes, and thrombocytopenia) syndrome. Am J Obstet Gynecol 1997; 177: 1011-1017

223 Tompkins MJ, Thiagarajah S. HELLP (hemolysis, elevated liver enzymes, and low platelet count) syndrome: the benefit of corticosteroids. Am J Obstet Gynecol 1999; 181: 304-309

224 O'Brien JM, Milligan DA, Barton JR. Impact of high-dose corticosteroid therapy for patients with HELLP (hemolysis, elevated liver enzymes, and low platelet count) syndrome. Am J Obstet Gynecol 2000; 183: 921-924
225 Schlembach D, Munz W, Fischer T. Effect of corticosteroids on HELLP syndrome: a case report. J Perinat Med 2000; 28: 502-505

226 Isler CM, Barrilleaux PS, Magann EF et al. A prospective, randomized trial comparing the efficacy of dexamethasone and betamethasone for the treatment of antepartum HELLP (hemolysis, elevated liver enzymes, and low platelet count) syndrome. Am J Obstet Gynecol 2001; 184: 1332-1337

227 Mecacci F, Carignani L, Cioni R et al. Time course of recovery and complications of HELLP syndrome with two different treatments: heparin or dexamethasone. Thromb Res 2001; 102: 99-105

228 Varol F, Aydin T, Gucer F. HELLP syndrome and postpartum corticosteroids. Int J Gynaecol Obstet 2001; 73: 157-159

229 O'Brien JM, Shumate SA, Satchwell SL et al. Maternal benefit of corticosteroid therapy in patients with HELLP (hemolysis, elevated liver enzymes, and low platelet count) syndrome: impact on the rate of regional anesthesia. Am J Obstet Gynecol 2002; 186: 475-479

230 Crane JM, Tabarsi B, Hutchens D. The maternal benefits of corticosteroids with HELLP (hemolysis, elevated liver enzymes, low platelet count) syndrome. J Obstet Gynaecol Can 2003; 25: 650-655

231 Isler CM, Magann EF, Rinehart BK et al. Dexamethasone compared with betamethasone for glucocorticoid treatment of postpartum HELLP syndrome. Int J Gynaecol Obstet 2003; 80: 291-297

232 Martin JN jr., Thigpen BD, Rose CH et al. Maternal benefit of high-dose intravenous corticosteroid therapy for HELLP syndrome. Am J Obstet Gynecol 2003; 189: 830-834

233 Fonseca JE, Méndez F, Cataño C et al. Dexamethasone treatment does not improve the outcome of women with HELLP syndrome: a doubleblind, placebo-controlled, randomized clinical trial. Am J Obstet Gynecol 2005; 193: 1591-1598

234 Woudstra DM, Chandra S, Hofmeyr GJ et al. Corticosteroids for HELLP (hemolysis, elevated liver enzymes, low platelets) syndrome in pregnancy. Cochrane Database Syst Rev 2010; (9): CD008148

235 Sullivan CA, Magann EF, Perry KG jr. et al. The recurrence risk of the syndrome of hemolysis, elevated liver enzymes, and low platelets (HELLP) in subsequent gestations. Am J Obstet Gynecol 1994; 171: 940-943

236 Van Pamus MG, Wolf H, Mayruhu G et al. Long-term follow-up in patients with a history of (H)ELLP syndrome. Hypertens Pregnancy 2001; 20: 15-23 


\section{Guideline Program}

\section{Editors}

Leading Professional Medical Associations

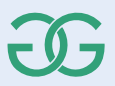

German Society of Gynecology and Obstetrics (Deutsche Gesellschaft für Gynäkologie und Geburtshilfe e. V. [DGGG])

Head Office of DGGG and Professional Societies Hausvogteiplatz 12

DE-10117 Berlin

info@dggg.de

http://www.dggg.de/

\section{President of DGGG}

Prof. Dr. med. Diethelm Wallwiener

Universitätsfrauenklinik Tübingen

Calwerstraße 7

DE-72076 Tübingen

DGGG Guidelines Representative

Prof. Dr. med. Matthias W. Beckmann

Universitätsklinikum Erlangen-Nürnberg

Frauenklinik

Universitätsstraße 21-23

DE-91054 Erlangen

\section{Guidelines Coordination}

Dr. med. Paul Gaß, Tobias Brodkorb, Marion Gebhardt Universitätsklinikum Erlangen-Nürnberg

Frauenklinik

Universitätsstraße 21-23

DE-91054 Erlangen

fk-dggg-leitlinien@uk-erlangen.de

http://www.dggg.de/leitlinienstellungnahmen

\section{OEGGG}

Austrian Society of Gynecology and Obstetrics (Österreichische Gesellschaft für Gynäkologie und Geburtshilfe [OEGGG])

Innrain 66A

AT-6020 Innsbruck

stephanie.leutgeb@oeggg.at

http://www.oeggg.at

President of OEGGG

Prof. Dr. med. Uwe Lang

Universitätsklinik für Frauenheilkunde und Geburtshilfe Graz

Auenbruggerplatz 14

AT-8036 Graz

OEGGG Guidelines Representative

Prof. Dr. med. Karl Tamussino

Universitätsklinik für Frauenheilkunde

und Geburtshilfe Graz

Auenbruggerplatz 14

AT-8036 Graz

\section{gynécologie}

suisse

Swiss Society of Gynecology and Obstetrics (Schweizerische Gesellschaft für Gynäkologie und Geburtshilfe [SGGG])

Gynécologie Suisse SGGG

Altenbergstraße 29

Postfach 6

CH-3000 Bern 8

sekretariat@sggg.ch

http://www.sggg.ch/

President of SGGG

Dr. med. David Ehm

FMH für Geburtshilfe und Gynäkologie

Nägeligasse 13

CH-3011 Bern

SGGG Guidelines Representative

Prof. Dr. med. Daniel Surbek

Universitätsklinik für Frauenheilkunde

Geburtshilfe und feto-maternale Medizin

Inselspital Bern

Effingerstraße 102

CH-3010 Bern 